\title{
Efficacy And Safety of Blood Derivatives Therapy in Alzheimer's Disease: A Systematic Review And Meta-Analysis
}

\author{
Zhangcheng Fei ( $\checkmark$ zhangchengfei94@163.com) \\ Bo Pan \\ Chinese Academy of Medical Sciences \& Peking Union Medical College \\ Renjun Pei \\ Chinese Academy of Medical Sciences \& Peking Union Medical College \\ Zhongsheng Chen \\ Chinese Academy of Medical Sciences \& Peking Union Medical College \\ Xi Du \\ Chinese Academy of Medical Sciences \& Peking Union Medical College \\ Haijun Cao \\ Chinese Academy of Medical Sciences \& Peking Union Medical College \\ Changqing Li \\ Chinese Academy of Medical Sciences \& Peking Union Medical College
}

Chinese Academy of Medical Sciences \& Peking Union Medical College https://orcid.org/0000-0002-3261-7385

Research

Keywords: Blood derivatives, Alzheimer's disease, IVIG, plasma exchange, plasma infusion, meta-analysis

Posted Date: December 20th, 2021

DOI: https://doi.org/10.21203/rs.3.rs-1153154/v1

License: (c) (1) This work is licensed under a Creative Commons Attribution 4.0 International License. Read Full License 


\section{Abstract}

Objective: Blood derivatives therapy is a conventional clinical treatment, while the treatment for Alzheimer's disease (AD) is relatively novel. To provide clinical references for treating $A D$, this meta-analysis was performed to evaluate the efficacy and safety of blood derivatives therapy on the patients with $A D$.

Methods: A systematic articles search was performed for eligible studies published up to December 6, 2021 through the PubMed, Embase, Cochrane library, ClinicalTrials.gov, Chinese National Knowledge Infrastructure database and Wanfang databases. The included articles were screened by using rigorous inclusion and exclusion criteria. Random effects model was used for this meta-analysis when there is heterogeneity, or else fixed effects model was used. Quality of studies and risk of bias were evaluated.

Results: A total of 3 plasma administrations (2 plasma exchange and 1 young plasma infusion) and 5 intravenous immunoglobulin (IVIG) randomized controlled trials with a sample size of 1148 subjects diagnosed with AD were included. There was no significant difference in cognitive improvement and all-cause discontinuation between intervention and placebo groups. In subgroup analysis, plasma administration was superior to placebo only in limited studies for individual scales. IVIG is well tolerated for AD patients even under the maximum dose $(0.4 \mathrm{~g} / \mathrm{kg})$, but it's inferior to placebo in Neuropsychiatric Inventory scale in AD patients $(P=0.05)$.

Conclusions: The benefits of blood derivatives therapy for AD are limited. It's necessary to perform well-designed randomized controlled trials with large sample sizes focusing on the appropriate blood derivatives for the specific AD sub-populations in the future.

Systematic review registration: PROSPERO CRD42021233886.

\section{Introduction}

As the most common cause of dementia, Alzheimer's disease (AD) is characterized by progressive cognitive impairment and personality changes[1]. The prevalence of $A D$ is rapidly increasing with the coming acceleration of global population aging, which has been a huge burden to social public expenditure[2-4]. The pathogenesis of AD is complicated and involves widely[5-9]. There are no known effective therapeutics for $A D$, so it's urgent to seek out a variety of potential treatments that can improve or preserve cognitive function.

Blood derivatives therapy is a conventional treatment that consists of a range of clinical measures, which aims to treat the illness by using blood derivatives such as plasma, blood cells, immunoglobulin, coagulation factor, albumin, and other blood components. Aside from anemia and bleeding, blood derivatives have been utilized in a variety of diseases on account of the diversity of blood components $[10,11]$. Currently, the most common blood derivatives therapies for $A D$ are plasma exchange (PE), plasma infusion and intravenous immunoglobulin (IVIG). PE and young plasma infusion are beneficial in improving the cognitive function of AD patients in some pilot studies[12]. It has been verified that the tissues of the aged mice were rejuvenated and the cognitive function was improved after diluting blood plasma or infusion of young plasma[13, 14]. Although the explicit mechanism is unclear, it may be related to the particular plasma components. IVIg, containing the full range of antibody spectrum, is derived from the plasma of thousands of healthy donors. It has been used to treat patients with autoimmune diseases for decades[15-18]. Moreover, it has been demonstrated that in addition to anti-amyloid- $\beta$ (A $\beta$ ), IVIG also has anti-inflammatory and immunomodulatory functions[19-21]. On the basis of these benefits, IVIG may be a potential treatment for AD.

At present, there are some randomized controlled trials (RCTs) focusing on the efficacy of blood derivatives therapy for AD, but the obtained conclusions are conflicted[22-24]. In this study, we systematically retrieved the related studies and performed this metaanalysis to evaluate the efficacy of blood derivatives therapy for patients with AD. The safety was also investigated in light of the fact that the majority of $A D$ patients are old and vulnerable to adverse events.

\section{Methods}

This study was designed and conducted according to the Preferred Reporting Items for Systematic Reviews and Meta-analyses (PRISMA) reporting guideline (Supplementary)[25]. The review has been registered with PROSPERO

(http://www.crd.york.ac.uk/PROSPERO/.CRD42021233886).

Design and Search Strategy

The search included articles in English or Chinese language published in the PubMed, Embase, Cochrane library, ClinicalTrials.gov, Chinese National Knowledge Infrastructure database and Wanfang databases through December 6, 2021. The search was conducted 
using the following keywords: Alzheimer* or cognitive dysfunction or Cognitive Impairment or dementia and blood or plasma or Immunoglobulins, Intravenous or IVIG or Antibodies, Intravenous or transfusion or apheresis or albumin and randomized controlled trial or controlled clinical trial. The detailed retrieval strategy can be found in the supplementary. The references to the included articles and reviews were also searched for citations of additional relevant published and unpublished studies.

Criteria for inclusion

Inclusion criteria for the systematic review were (1) a randomized controlled study design that did not require mortality data to ascertain outcome; (2) all subjects were diagnosed with AD; (3) experimental group was not given intervention other than blood derivatives under the guarantee of basic medical care; (4) related scales such as Alzheimer Disease Assessment Scale-Cog (ADAS-cog) were used to evaluate the cognitive function of experimental group and control group before and after the intervention.

Criteria for exclusion

Studies were excluded if (1) study reported insufficient details to derive the study outcomes; (2) study had other interventions; (3) the full text of the study was not available in the databases; (4) study was written in languages other than English and Chinese.

Study Outcomes

We assessed the primary outcomes of this study including an efficacy measure, improvement in ADAS-cog, which is considered the gold standard for assessing the efficacy of antidementia treatments[26], and a safety measure, all-cause discontinuation. The secondary outcomes including scores of MMSE, Alzheimer's Disease Cooperative Study/Activities of Daily Living (ADCS-ADL)[27], Neuropsychiatric Inventory(NPI)[28], the Alzheimer's Disease Cooperative Study-Clinical Global Impressions of Change (ADCS-CGIC)[29], Clinical Dementia Rating scale-Sum of Boxes (CDR-sb)[30], and the quality of life in Alzheimer's disease (QOL-AD)[31], were assessed for efficacy. The secondary outcomes for safety were the reported adverse events.

\section{Data Extraction}

One investigator (FZC) performed the literature search and screening, and 2 investigators (BP, RJP) independently performed data extraction. Discrepancies were resolved through discussion between investigators. The extracted data items include (1) study design, country, study start and end dates, year of publication; (2) participant characteristics, including age, sex, race/ethnicity, size, source; (3) type of dementia, details of the intervention, treatment duration, and all clinical assessment scales.

Risk of Bias

We scored the studies that met inclusion criteria according to the Cochrane risk of bias tool[32], which evaluated the random sequence generation, allocation concealment, blinding of participants, personal and outcome assessment, incomplete outcome data, selective outcome reporting, and other biases (Figure 1). The included RCTs were classified as low risk (L), high risk (H) or unclear risk (U) in the above items.

\section{Results}

A total of 10315 references were identified from the databases (Figure 2). After excluding duplications and screening of titles and abstracts, the full papers of 191 studies were obtained and assessed for eligibility. According to the inclusion criteria, 8 studies were finally included[12, 23, 24, 33-37]. Plasma-related therapies for AD were summarized as plasma administration in this study. The definitive analysis included 3 plasma administration (2 PE and 1 plasma infusion) RCTs and 5 IVIG RCTs ( $n=1148$ ) published between 2012 and 2020 for individuals with AD from United States, Spain, Germany, Japan, and Canada. The concrete information of included studies was listed in Table 1. All analyses were conducted using Review Manager 5.4. Random effects model was used for this metaanalysis when there was heterogeneity, or else fixed effects model was used. There was no sensitivity analysis performed due to the limitation of data. 
Table 1

Characteristics of RCTs Included in this Systematic Review

\begin{tabular}{|c|c|c|c|c|c|c|c|c|c|c|}
\hline Source & $\begin{array}{l}\text { Study } \\
\text { design }\end{array}$ & $\begin{array}{l}\text { Total, } \\
\mathbf{n}\end{array}$ & $\begin{array}{l}\text { Subjects } \\
\text { (1) } \\
\text { Diagnosis } \\
(2) \\
\text { Inclusion } \\
\text { criteria } \\
\text { (3) } \\
\text { Intensity }\end{array}$ & $\begin{array}{l}\text { Age } \\
\text { (years), } \\
\text { mean } \\
\text { (SD) }\end{array}$ & $\begin{array}{l}\text { Baseline } \\
\text { cognitive } \\
\text { function } \\
\text { scales } \\
\text { Mean } \\
\text { (SD) }\end{array}$ & \multicolumn{2}{|c|}{$\begin{array}{l}\text { Intervention } \\
\text { (m=month, w=week) }\end{array}$} & Duration & $\begin{array}{l}\text { Efficacy } \\
\text { outcome }\end{array}$ & $\begin{array}{l}\text { Risk } \\
\text { of } \\
\text { Bias }\end{array}$ \\
\hline \multirow[t]{4}{*}{$\begin{array}{l}\text { Merce[12] 2020, } \\
\text { Spain and USA }\end{array}$} & \multirow[t]{4}{*}{ RCT } & \multirow[t]{4}{*}{322} & \multirow{4}{*}{$\begin{array}{l}\text { (1) AD } \\
\text { (2) Age } \\
55-85 y \text {, } \\
\text { MMSE } \\
18-26 \\
\\
\text { (3) Mild } \\
\text { to } \\
\text { moderate }\end{array}$} & \multirow[t]{4}{*}{$\begin{array}{l}69.0 \\
(7.7)\end{array}$} & \multirow[t]{4}{*}{$\begin{array}{l}21.6 \\
(2.6)\end{array}$} & \multirow[t]{4}{*}{$\begin{array}{l}6 \\
\text { Weekly } \\
\text { PE with } \\
\text { albumin } \\
5 \%\end{array}$} & $\begin{array}{l}\text { (1) } 20 \mathrm{~g} \\
\text { albumin, } \\
\mathrm{n}=78,12 \\
\text { monthly } \\
\text { infusions }\end{array}$ & \multirow[t]{4}{*}{$6 w+12 m$} & \multirow{4}{*}{$\begin{array}{l}\text { ADCS- } \\
\text { ADL, } \\
\text { ADAS- } \\
\text { COG, } \\
\text { ADCS- } \\
\text { CGIC, } \\
\text { CDR-sb }\end{array}$} & \multirow[t]{4}{*}{$\begin{array}{l}\text { L, L, } \\
\text { L, L, } \\
\text { U, U }\end{array}$} \\
\hline & & & & & & & $\begin{array}{l}\text { (2) } 20 \mathrm{~g} \\
\text { albumin } \\
+10 \mathrm{~g} \\
\text { IVIG 5\%, } \\
\mathrm{n}=86,12 \\
\text { monthly } \\
\text { infusions }\end{array}$ & & & \\
\hline & & & & & & & $\begin{array}{l}\text { (3) } 40 \mathrm{~g} \\
\text { albumin } \\
+20 \mathrm{~g} \\
\text { IVIG 5\%, } \\
\mathrm{n}=78,12 \\
\text { monthly } \\
\text { infusions }\end{array}$ & & & \\
\hline & & & & & & & $\begin{array}{l}(4) \\
\text { Placebo, } \\
\mathrm{n}=80,12 \\
\text { monthly } \\
\text { infusions }\end{array}$ & & & \\
\hline \multirow{3}{*}{$\begin{array}{l}\text { Sha[33] 2019, } \\
\text { USA }\end{array}$} & \multirow[t]{3}{*}{ RCT } & \multirow[t]{3}{*}{18} & (1) AD & \multirow{3}{*}{$\begin{array}{l}74.2 \\
(3.84)\end{array}$} & \multirow{3}{*}{$\begin{array}{l}19.39 \\
(3.24)\end{array}$} & \multirow{2}{*}{\multicolumn{2}{|c|}{$\begin{array}{l}1 \text { Unit young plasma } \\
\text { / placebo }, 4 \text { weekly } \\
\text { infusions }+6-w \\
\text { washout }+4 \text { weekly } \\
\text { infusions, } n=9\end{array}$}} & \multirow[t]{3}{*}{$14 w$} & \multirow{3}{*}{$\begin{array}{l}\text { ADCS- } \\
\text { ADL, } \\
\text { ADAS- } \\
\text { COG, } \\
\text { CDR-sb, } \\
\text { NPI }\end{array}$} & \multirow{3}{*}{$\begin{array}{l}\mathrm{L}, \mathrm{L}, \\
\mathrm{L}, \mathrm{U} \\
\mathrm{H}, \mathrm{U}\end{array}$} \\
\hline & & & $\begin{array}{l}\text { (2) Age } \\
50-90 \mathrm{y} \\
\text { MMSE } \\
12-24\end{array}$ & & & & & & & \\
\hline & & & $\begin{array}{l}\text { (3) Mild } \\
\text { to } \\
\text { moderate }\end{array}$ & & & \multicolumn{2}{|c|}{$\begin{array}{l}1 \text { Unit young plasma } \\
4 \text { weekly infusions, } \\
n=9\end{array}$} & & & \\
\hline \multirow[t]{2}{*}{$\begin{array}{l}\text { NCT00742417[34] } \\
\text { 2017, Spain and } \\
\text { USA }\end{array}$} & \multirow[t]{2}{*}{ RCT } & \multirow[t]{2}{*}{37} & $\begin{array}{l}\text { (1) AD } \\
\text { (2) Age } \\
55-85 \mathrm{y} \\
\text { MMSE } \\
18-26\end{array}$ & \multirow[t]{2}{*}{$\begin{array}{l}67.7 \\
(7.9)\end{array}$} & \multirow[t]{2}{*}{$\begin{array}{l}21.5 \\
(2.8)\end{array}$} & \multicolumn{2}{|c|}{$\begin{array}{l}2 \text { PE } 3 \text { weekly }+1 \text { PE } \\
6 \text { weekly }+1 \text { PE } 6 \text { bi- } \\
\text { weekly, } n=18\end{array}$} & \multirow[t]{2}{*}{$\begin{array}{l}21 \mathrm{w}+6 \mathrm{~m} \\
(21 \mathrm{w} \\
\text { dosing } \\
\text { period and } \\
6 \mathrm{~m} \\
\text { observation } \\
\text { period) }\end{array}$} & \multirow{2}{*}{$\begin{array}{l}\text { MMSE, } \\
\text { ADAS- } \\
\text { Cog, } \\
\text { ADCS- } \\
\text { ADL, } \\
\text { ADCS- } \\
\text { CGIC, } \\
\text { CDR-sb, } \\
\text { NPI }\end{array}$} & \multirow[t]{2}{*}{$\begin{array}{l}\mathrm{L}, \mathrm{L}, \\
\mathrm{L}, \mathrm{U} \\
\mathrm{U}, \mathrm{U}\end{array}$} \\
\hline & & & $\begin{array}{l}\text { (3) Mild } \\
\text { to } \\
\text { moderate }\end{array}$ & & & \multicolumn{2}{|c|}{ Placebo, 21 w. n=19 } & & & \\
\hline \multirow[t]{2}{*}{ Kile[35] 2017, USA } & \multirow[t]{2}{*}{ RCT } & \multirow[t]{2}{*}{49} & (1) $A D$ & \multirow[t]{2}{*}{$\begin{array}{l}72.3 \\
(7.56)\end{array}$} & \multirow[t]{2}{*}{$\begin{array}{l}26.6 \\
(2.4)\end{array}$} & \multicolumn{2}{|c|}{$\begin{array}{l}\text { IVIG } 10 \%, 0.4 \mathrm{~g} / \mathrm{kg} \text {, } \\
\text { bi-weekly. } \mathrm{n}=24\end{array}$} & \multirow{2}{*}{$\begin{array}{l}104 \mathrm{w} \text { (10 } \\
\text { w dosing } \\
\text { period and } \\
94 \mathrm{w} \\
\text { observation } \\
\text { period) }\end{array}$} & $\begin{array}{l}\text { MMSE, } \\
\text { ADAS- }\end{array}$ & $\begin{array}{l}\text { L, L, } \\
\text { L, L, }\end{array}$ \\
\hline & & & $\begin{array}{l}50-84 \text { y, } \\
\text { MMSE } \\
24-30\end{array}$ & & & $\begin{array}{l}\text { Placebo, } \\
n=25\end{array}$ & i-weekly. & & CDR-sb, & \\
\hline
\end{tabular}

(3) $\mathrm{MCl}$

PE, plasma exchange with $5 \%$ human albumin: 1 plasma volume was processed in $1 \mathrm{PE}$, the same volume of $5 \%$ albumin as the substitute fluid. MCl: mild cognitive impairment. NR: not reported. 


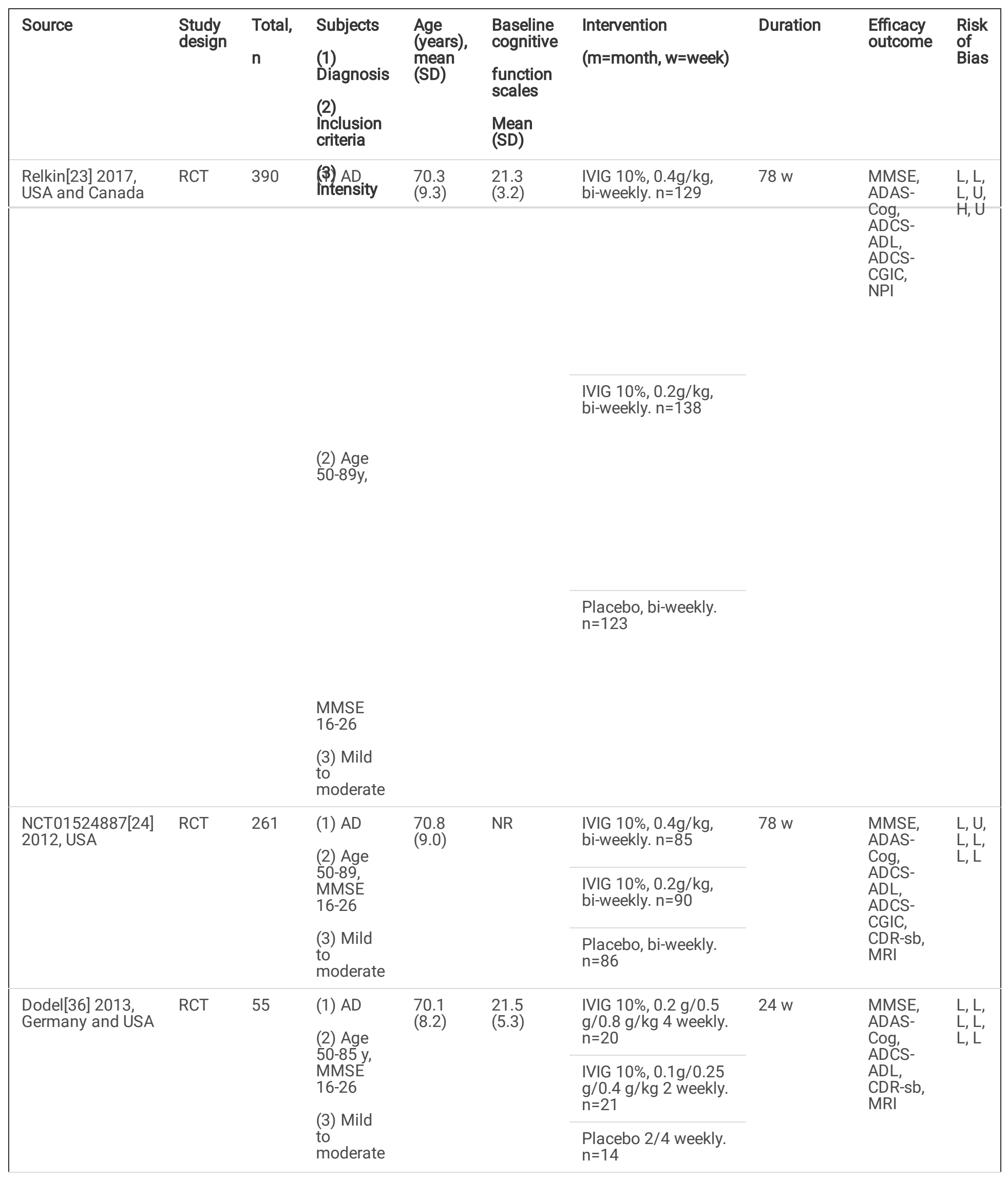

$\mathrm{PE}$, plasma exchange with $5 \%$ human albumin: 1 plasma volume was processed in $1 \mathrm{PE}$, the same volume of $5 \%$ albumin as the substitute fluid. MCl: mild cognitive impairment. NR: not reported. 


\begin{tabular}{|c|c|c|c|c|c|c|c|c|c|}
\hline Source & $\begin{array}{l}\text { Study } \\
\text { design }\end{array}$ & $\begin{array}{l}\text { Total, } \\
\text { n }\end{array}$ & $\begin{array}{l}\text { Subjects } \\
(1) \\
\text { Diagnosis } \\
(2) \\
\text { Inclusion } \\
\text { criteria }\end{array}$ & $\begin{array}{l}\text { Age } \\
\text { (years), } \\
\text { mean } \\
\text { (SD) }\end{array}$ & $\begin{array}{l}\text { Baseline } \\
\text { cognitive } \\
\text { function } \\
\text { scales } \\
\text { Mean } \\
\text { (SD) }\end{array}$ & $\begin{array}{l}\text { Intervention } \\
\text { ( } m=\text { month, w=week) }\end{array}$ & Duration & $\begin{array}{l}\text { Efficacy } \\
\text { outcome }\end{array}$ & $\begin{array}{l}\text { Risk } \\
\text { of } \\
\text { Bias }\end{array}$ \\
\hline \multirow[t]{5}{*}{$\begin{array}{l}\text { Arial[37] 2014, } \\
\text { Japan }\end{array}$} & RCT & 16 & $\begin{array}{l}\text { (३) } A D \\
\text { Intensity }\end{array}$ & 72.6 & 20.0 & $\begin{array}{l}\text { IVIG } 10 \%, 0.4 \mathrm{~g} / \mathrm{kg} \\
\text { bi-weekly. } \mathrm{n}=6\end{array}$ & $\begin{array}{l}26 \mathrm{w}(12 \mathrm{w} \\
\text { dosing }\end{array}$ & MMSE & \multirow{5}{*}{$\begin{array}{l}\text { U, U, } \\
\text { L, U, } \\
\text { U, U }\end{array}$} \\
\hline & & & & & & $\begin{array}{l}\text { IVIG } 10 \%, 0.2 \mathrm{~g} / \mathrm{kg} \\
\text { bi-weekly. } \mathrm{n}=6 \\
\text { Placebo, bi-weekly. } \\
\mathrm{n}=4\end{array}$ & $\begin{array}{l}\text { period and } \\
14 \mathrm{w} \\
\text { observation } \\
\text { period) }\end{array}$ & & \\
\hline & & & $\begin{array}{l}\text { (2) Age, } \\
50-89 y\end{array}$ & & & & & & \\
\hline & & & $\begin{array}{l}\text { MMSE } \\
16-26\end{array}$ & & & & & & \\
\hline & & & $\begin{array}{l}\text { (3) Mild } \\
\text { to } \\
\text { moderate }\end{array}$ & & & & & & \\
\hline
\end{tabular}

Results of the meta-analysis regarding efficacy outcomes

Cognitive effects were measured by ADAS-Cog, ADCS-ADL, NPI in all the included studies. There was no significant difference in ADASCog scores between the intervention (plasma and IVIG) and placebo groups (Figure 3a). For plasma groups, 2 RCTs with 351 patients were included in this meta-analysis[12,34]. The change of ADAS-Cog score was MD $-1.20,95 \% \mathrm{Cl}-3.77$ to $1.37, \mathrm{P}=0.36, \mathrm{I}=0 \%$. It means that plasma administration did not effectively improve the cognition of patients with AD. For IVIG, 4 RCTs with 485 patients were included $[23,24,35,36]$. The change of ADAS-Cog score was MD 0.82, 95\% Cl -0.58 to 2.22, P =0.25, I2 =0\%. IVIG also did not achieve satisfactory performance in improving cognitive function.

In the subgroup analysis, there was no significant difference between plasma administration and placebo in terms of ADCS-ADL ( $P$ $=0.21)$ and NPI ( $=0.66)$ scores. It suggested that plasma administration had almost nothing to do with improvement in cognitive function. For IVIG, the maximum dosage of IVIG was superior to placebo group in terms of ADCS-ADL (Figure 3b): MD -5.14, 95\% CI -9.03 to $-1.25, \mathrm{P}=0.01, \mathrm{I}=0 \%$. However, IVIG administration was inferior to placebo group in terms of NPI scores (Figure 3c): MD 2.19, 95\% CI 0.02 to $4.37, P=0.05,12=0 \%$.

Results of the meta-analysis regarding safety outcomes

All the included studies were performed a safety meta-analysis. It's found that no significant differences between blood derivatives group and placebo group in the number of patients with all-cause discontinuation rates (Figure $4 \mathrm{a}, \mathrm{RR} 1.10,95 \% \mathrm{Cl} 0.79$ to $1.54, P=0.58, P=$ 
0\%). However, plasma administration was associated with a higher incidence of adverse events (Figure 4b): RR 1.29, 95\% Cl 1.13 to 1.47, $P=0.0001, R=0 \%$. There was no difference in adverse events when comparing IVIG with placebo for AD patients (Figure $4 \mathrm{~b}$ ): RR $1.02,95 \%$ Cl 0.87 to $1.20, P=0.80, R=0 \%$.

\section{Discussion}

This is the first comprehensive meta-analysis to evaluate the efficacy and safety of blood derivatives therapy for treating AD. In order to ensure the credibility of the meta-analysis, this meta-analysis only includes RCTs with high-quality evidence. All non-randomized controlled trials such as cohort studies were excluded. Similarly, preprints that have not been peer-reviewed will not be included.

For efficacy, the difference in all scores scale between plasma administration and placebo groups did not meet statistical significance. But in Merce 2020[12], PE was superior to placebo group in terms of CDR-sb and ADCS-CGIC scores, especially for patients with mild AD. And in Sha 2019[33], young plasma infusion group performed better than placebo group in terms of ADCS-ADL scores. No significant changes were found in the plasma $A \beta$ clearance when comparing plasma administration with the placebo[12, 34].

$\mathrm{PE}$ has been routinely utilized to treat various diseases such as Guillain-Barré syndrome[38], peripheral neurological conditions[39], and kidney disease[40]. Although the treatment of $A D$ with $P E$ is not fully developed, it does have a theoretical basis such as sink hypothesis[41]. According to the hypothesis, $A \beta$ levels are a dynamic equilibrium in cerebrospinal fluid (CSF) and plasma[42]. So CSF $A \beta$ levels fall when the plasma $A \beta$ are removed by $P E$, which may be beneficial to $A D[43]$. In addition, the blood of the elderly may contain certain aging factors, and PE may reduce the damage of these factors to bodily tissues[44]. It has been found that the level of plasma $\beta 2$ microglobulin ( $\beta 2 \mathrm{M})$ and $\mathrm{C}-\mathrm{C}$ motif chemokine 11 (CCL11) rise with age[45, 46]. $\beta 2 \mathrm{M}$ promotes aging in adults by accelerating age-related neurogenic decline and hippocampal-dependent cognitive impairment[47]. Plasma levels of CCL11 are negatively associated with memory function in patients with $\mathrm{AD}[48]$. Some studies have shown that CCL11 may act a neurotoxic role in the pathophysiology of $A D[49]$. PE might provide beneficial effects on $A D$ patients by decreasing $\beta 2 M, C C L 11$ and other unknown aging factors. The learning and memory function of old mice was considerably improved when they were infused with young plasma[50]. Therefore, the circulating factors in young plasma may have a beneficial effect on human cognition. For example, thrombospondin-4, an abundant protein in young blood, can promote synaptogenesis and nourish nerves[51]. And the tissue inhibitor of metalloproteinases 2, a blood-borne factor enriched in human cord plasma and young mouse plasma, has been shown to increase synaptic plasticity and hippocampal-dependent cognition in aged mice[52].

Albumin, the protein with the highest content in plasma, is very important for maintaining plasma osmotic pressure. So it's frequently used as the replacement solution in PE. Ectopic albumin has a positive effect on the proliferation of neural precursor cells [53, 54]. It has been found that replacing half of the plasma of aged mice with a mixture of saline and albumin even is enough to rejuvenate the brain[54].

Given these reasons, plasma administration, including PE and plasma infusion, retains therapeutic potential in the treatment of AD. But it needs not only more sophisticated RCTs but also further studies on anti-aging and aging factors in plasma in the future. For safety, plasma administration has a higher incidence of adverse reactions, which may be related to the invasiveness of the treatment and the complexity of plasma component. Although the majority of these adverse events are not lethal and easy to manage such as blood pressure changes, dizziness, infection, they should be dealt with carefully since older people are more vulnerable to these occurrences.

The production, processing and clearance of $A \beta$ are believed to be the earliest and the most important steps in the pathogenesis of $A D$ [55]. Early treatment of $A \beta$-related abnormalities could preemptively prevent the downstream pathogenic factors of the cascade of $A D$, thereby improving the progression of AD. It has been demonstrated that IVIG contains anti-A $\beta$ antibody, which can promote the removal of natively formed brain $A \beta$ deposits[56]. However, no significant difference was found between IVIG and placebo treatment groups in terms of ADAS-Cog scores. The high dose $(0.4 \mathrm{~g} / \mathrm{kg})$ IVIG group does not achieve better effects in all scores scale other than ADCS-ADL scores $(P=0.01)$. Although the results are disappointing, IVIG may improve $\mathrm{MCl}$ and brain atrophy in the short term[35]. There was no significant difference in cognitive improvement between IVIG and placebo group after 2 years of intervention, but IVIG alleviated brain atrophy and improved significantly cognitive function in patients with $\mathrm{MCl}$ within 1 year[35]. It suggested that IVIG could be more helpful in the treatment of the ultra-early course of AD.

IVIG group performed the worst in NPI scores, which is often used to evaluate the neurological and mental status of the elderly with dementia, suggesting IVIG deteriorated behavioral and psychological symptoms of AD patients[57]. A possible explanation is that IVIG decreased CSF A $\beta$ levels quickly[23], which is proven to be related to an increase in neuropsychiatric symptoms[58]. Reportedly, the anti-

Page $7 / 16$ 
inflammatory cytokine IL-10 showed reverse correlations with total NPI score (the score of 0 is the best in NPI scale) in patients with $A D[59]$, and the presence of IVIG significantly increases the expression of IL-10 in vivo and vitro[60, 61]. But it's unlikely to apply the higher dose IVIG to increase its anti-inflammatory effects, considering the risk of possible adverse events[62, 63]. AD-specific IVIG may be an alternative approach because it could contain higher concentrations of selected antibodies such as anti-A $\beta$, anti-tau protein, and antiinflammatory after purification and recombination and recombinant polyclonal antibody technology[64-68]. Besides, there is growing consensus that cognitive impairment may be due to the neurotoxicity of A $\beta$ oligomers[69]. Therefore, the development of specific IVIG for $A \beta$ oligomers rather than monomers may be another therapeutic option. The $A \beta$ antibody content of IVIG from different manufacturers and even different batches were significantly different because IVIG was prepared from the mixed plasma of different people. But there have been no studies comparing the effects of different IVIG products in AD patients, so whether one product would be preferable to another is unknown. For safety, there is no significant difference between IVIG and placebo in all-cause discontinuation and adverse events. So, IVIG is a safe treatment.

Since the amyloid cascade hypothesis was published in 1991, AD therapy has focused primarily on monoclonal anti-A $\beta$ antibodies[70], $\beta$ secretase inhibitors[71], and $\gamma$-secretase modulators[72] and inhibitors[73]. But they did not successfully slow down the progressive loss of cognitive function in patients with $A D$. Single-target drug may not well interfere with the progression of $A D$ with complex pathogenesis. Plasma is rich in antibody spectrum and beneficial factors, which may be an important resource for searching for drugs against AD. In addition to plasma and IVIG, a new blood derivative GRF6019 has been developed and used in AD research[74]. GRF6019 is made from mixed plasma from healthy donors but depletes immunoglobulins and coagulation factors. It demonstrated excellent safety, feasibility, and tolerability in a pilot trial for the treatment of mild to severe AD patients[75]. Future trials designed to characterize the potential functional benefits of GRF6019 and related plasma fractions in AD are warranted.

Of course, several limitations may affect the results of our meta-analysis. Firstly, although the search strategy is strict, we may not be able to include certain studies, such as non-English or non-Chinese and publications that are not in the searched database. Secondly, the data gathered is limited since this meta-analysis only covers RCTs with high-quality evidence. And the included RCTs were mainly conducted in the United States so that the data was only marginally representative. Finally, we can't exclude the effect of publication bias and the potential effects caused by some confounders.

In conclusion, blood derivatives therapy is a safe treatment for AD. But this meta-analysis suggests that blood derivatives therapy is limited to improve cognition. Larger and longer RCTs are needed in the future to confirm the real clinical potential of blood derivatives therapy in $\mathrm{AD}$, especially for $\mathrm{MCl}$ patients. Because of the complexities of the plasma component and pathogenesis of $A D$, which plasma components can play a role in the treatment of $A D$ should be investigated. Apolipoprotein $E 4$ (ApoE4) is the strongest genetic risk factor for $A D[76]$, and positive cognitive signals were observed in subgroup analyses among APOE- $\varepsilon 4$ carriers in a phase III trial of IVIG for AD in North America[77]. It remains to be studied what components of IVIG can improve the cognitive function of AD patients with APOE- $\varepsilon 4$. This is helpful for the targeted therapy of AD sub-populations with blood derivatives.

\section{Declarations}

\section{Statement of Ethics}

This does not involve experiments on human subjects and animal subjects. No conflict of interest exists in the submission of this manuscript.

\section{Conflicts of Interest Statement}

The authors do not have any conflicts of interest to declare.

\section{Funding Sources}

This study was supported by the Science and Technology Project of Sichuan (No. 2019YFS0105) and the Scientific Research Project of Sichuan Health Committee (NO. 19PJ305).

\section{Author Contributions}

FZC, PB, PRJ, DX, CZS, CHJ, LCQ were involved in review conception and design. FZC and CHJ developed the review protocol. PB, PRJ and CZS performed searches, identified publications to include in the review, synthesised results. FZC wrote the first draft of the review. $\mathrm{CHJ}$ critically revised manuscript. 
All data generated or analysed during this study are included in this. Further enquiries can be directed to the corresponding author.

\section{References}

1. Ossenkoppele R, Pijnenburg YA, Perry DC, Cohn-Sheehy BI, Scheltens NM, Vogel JW, Kramer JH, van der Vlies AE, Joie RL, Rosen HJ (2015) The behavioural/dysexecutive variant of Alzheimer's disease: clinical, neuroimaging and pathological features. Brain 138, 2732-2749.

2. (2020) 2020 Alzheimer's disease facts and figures. Alzheimer's \& Dementia 16, 391-460.

3. Long JM, Holtzman DM (2019) Alzheimer Disease: An Update on Pathobiology and Treatment Strategies. Cel/ 179, 312-339.

4. Cao H, Du X, Zeng R, Lv Z, Ye S, Jiang P, Wang Z, Ma L, Huang Y, Li C, Zhang R, Liu F (2019) Effect of Different A $A$ Aggregates as Antigen on the Measure of Naturally Occurring Autoantibodies against Amyloid-340/42 in IVIG. Curr Alzheimer Res 16, 1290-1299.

5. Leng F, Edison P (2021) Neuroinflammation and microglial activation in Alzheimer disease: where do we go from here? Nat Rev Neurol 17, 157-172.

6. Chen Y, Strickland MR, Soranno A, Holtzman DM (2021) Apolipoprotein E: Structural Insights and Links to Alzheimer Disease Pathogenesis. Neuron 109, 205-221.

7. Hampel H, Vassar R, De Strooper B, Hardy J, Willem M, Singh N, Zhou J, Yan R, Vanmechelen E, De Vos A, Nisticò R, Corbo M, Imbimbo BP, Streffer J, Voytyuk I, Timmers M, Tahami Monfared AA, Irizarry M, Albala B, Koyama A, Watanabe N, Kimura T, Yarenis L, Lista S, Kramer L, Vergallo A (2021) The $\beta$-Secretase BACE1 in Alzheimer's Disease. Biol Psychiatry 89, 745-756.

8. John A, Reddy PH (2021) Synaptic basis of Alzheimer's disease: Focus on synaptic amyloid beta, P-tau and mitochondria. Ageing Res Rev 65, 101208.

9. Ayton S, Bush Al (2021) ß-amyloid: The known unknowns. Ageing Res Rev 65, 101212.

10. Belk JW, Kraeutler MJ, Houck DA, Goodrich JA, Dragoo JL, McCarty EC (2021) Platelet-Rich Plasma Versus Hyaluronic Acid for Knee Osteoarthritis: A Systematic Review and Meta-analysis of Randomized Controlled Trials. Am J Sports Med 49, $249-260$.

11. Erdoes G, Koster A, Ortmann E, Meesters MI, Bolliger D, Baryshnikova E, Martinez Lopez De Arroyabe B, Ahmed A, Lance MD, Ranucci M, von Heymann C, Agarwal S, Ravn HB (2021) A European consensus statement on the use of four-factor prothrombin complex concentrate for cardiac and non-cardiac surgical patients. Anaesthesia 76, 381-392.

12. Mercè B, L LO, Javier O, Laura N, Michael P, María P, Jesús L, Gerard P, E GJ, Fernando A, Dobri K, José L, Carlota G, Mireia T, Montserrat C, Jordi B, M SZ, Suzanne H, Antonio P (2020) A randomized, controlled clinical trial of plasma exchange with albumin replacement for Alzheimer's disease: Primary results of the AMBAR Study. Alzheimer's \& Dementia 16, 1412-1425.

13. Mehdipour M, Mehdipour T, Skinner CM, Wong N, Liu C, Chen C-C, Jeon OH, Zuo Y, Conboy MJ, Conboy IMJG (2020) Plasma dilution improves cognition and attenuates neuroinflammation in old mice. GeroScience, 1-18.

14. Conboy IM, Conboy MJ, Wagers AJ, Girma ER, Weissman IL, Rando TAJN (2005) Rejuvenation of aged progenitor cells by exposure to a young systemic environment. Nature 433, 760-764.

15. Henderson LA, Canna SW, Friedman KG, Gorelik M, Lapidus SK, Bassiri H, Behrens EM, Ferris A, Kernan KF, Schulert GS, Seo P, Son MBF, Tremoulet AH, Yeung RSM, Mudano AS, Turner AS, Karp DR, Mehta JJ (2021) American College of Rheumatology Clinical Guidance for Multisystem Inflammatory Syndrome in Children Associated With SARS-CoV-2 and Hyperinflammation in Pediatric COVID-19: Version 2. Arthritis Rheumatol 73, e13-e29.

16. Bien CG (2021) Management of autoimmune encephalitis. Curr Opin Neuro/34, 166-171.

17. Dilley M, Wangberg H, Noone J, Geng B (2021) Primary immunodeficiency diseases treated with immunoglobulin and associated comorbidities. Allergy Asthma Proc 42, 78-86.

18. Vani J, Elluru S, Negi V-S, Lacroix-Desmazes S, Kazatchkine MD, Bayary J, Kaveri SVJAr (2008) Role of natural antibodies in immune homeostasis: IVIg perspective. Autoimmunity reviews 7, 440-444.

19. Dubey S, Heinen S, Krantic S, McLaurin J, Branch DR, Hynynen K, Aubert I (2020) Clinically approved IVIg delivered to the hippocampus with focused ultrasound promotes neurogenesis in a model of Alzheimer's disease. Proc Natl Acad Sci U S A 117, 32691-32700.

20. Krestova M, Hromadkova L, Bilkova Z, Bartos A, Ricny J (2017) Characterization of isolated tau-reactive antibodies from the IVIG product, plasma of patients with Alzheimer's disease and cognitively normal individuals. J Neuroimmuno/313, 16-24. 
21. Lünemann JD, Quast I, Dalakas MCJN (2016) Efficacy of intravenous immunoglobulin in neurological diseases. Neurotherapeutics $13,34-46$.

22. Loeffler DA (2020) AMBAR, an Encouraging Alzheimer's Trial That Raises Questions. Front Neuro/ 11, 459.

23. Relkin NR, Thomas RG, Rissman RA, Brewer JB, Rafii MS, van Dyck CH, Jack CR, Sano M, Knopman DS, Raman R, Szabo P, Gelmont DM, Fritsch S, Aisen PS (2017) A phase 3 trial of IV immunoglobulin for Alzheimer disease. Neurology 88, 1768-1775.

24. Nct (2012) Phase 3 IGIV, 10\% in Alzheimer's Disease. https://clinicaltrials.gov/show/NCT01524887.

25. Moher D, Liberati A, Tetzlaff J, Altman DG, medicine PGJP (2009) Preferred reporting items for systematic reviews and metaanalyses: the PRISMA statement. PLoS medicine 6, e1000097.

26. Kueper JK, Speechley M, Montero-Odasso M (2018) The Alzheimer's Disease Assessment Scale-Cognitive Subscale (ADAS-Cog): Modifications and Responsiveness in Pre-Dementia Populations. A Narrative Review. J Alzheimers Dis 63, 423-444.

27. Holthoff VA, Marschner K, Scharf M, Steding J, Meyer S, Koch R, Donix M (2015) Effects of physical activity training in patients with Alzheimer's dementia: results of a pilot RCT study. PLoS One 10, e0121478.

28. Canevelli M, Adali N, Voisin T, Soto ME, Bruno G, Cesari M, Vellas B (2013) Behavioral and psychological subsyndromes in Alzheimer's disease using the Neuropsychiatric Inventory. Int J Geriatr Psychiatry 28, 795-803.

29. Schneider LS, Clark CM, Doody R, Ferris SH, Morris JC, Raman R, Reisberg B, Schmitt FAJAD, Disorders A (2006) ADCS Prevention Instrument Project: ADCS-clinicians' global impression of change scales (ADCS-CGIC), self-rated and study partner-rated versions. Alzheimer Dis Assoc Disord 20, S124-138.

30. Miyagawa T, Brushaber D, Syrjanen J, Kremers W, Fields J, Forsberg LK, Heuer HW, Knopman D, Kornak J, Boxer A, Rosen H, Boeve B (2020) Use of the CDR® plus NACC FTLD in mild FTLD: Data from the ARTFL/LEFFTDS consortium. Alzheimers Dement 16, 79-90.

31. Stypa V, Haussermann P, Fleiner T, Neumann S (2020) Validity and Reliability of the German Quality of Life-Alzheimer's Disease (QoLAD) Self-Report Scale. J Alzheimers Dis 77, 581-590.

32. Higgins JP, Altman DG, Gøtzsche PC, Jüni P, Moher D, Oxman AD, Savović J, Schulz KF, Weeks L, Sterne JAJB (2011) The Cochrane Collaboration's tool for assessing risk of bias in randomised trials. BMJ 343, d5928.

33. Sha SJ, Deutsch GK, Tian L, Richardson K, Coburn M, Gaudioso JL, Marcal T, Solomon E, Boumis A, Bet A, Mennes M, van Oort E, Beckmann CF, Braithwaite SP, Jackson S, Nikolich K, Stephens D, Kerchner GA, Wyss-Coray T (2019) Safety, Tolerability, and Feasibility of Young Plasma Infusion in the Plasma for Alzheimer Symptom Amelioration Study: A Randomized Clinical Trial. JAMA Neurol 76, 35-40.

34. Nct (2017) Efficacy and Safety of Plasma Exchange With 5\% Albumin in Beta-amyloid Peptide Clearance in Cerebral Spinal Fluid. https://clinicaltrials.gov/show/NCT00742417.

35. Kile S, Au W, Parise C, Rose K, Donnel T, Hankins A, Chan M, Ghassemi A (2017) IVIG treatment of mild cognitive impairment due to Alzheimer's disease: a randomised double-blinded exploratory study of the effect on brain atrophy, cognition and conversion to dementia. Journal of neurology, neurosurgery, and psychiatry 88, 106-112.

36. Dodel R, Rominger A, Bartenstein P, Barkhof F, Blennow K, Förster S, Winter Y, Bach JP, Popp J, Alferink J, Wiltfang J, Buerger K, Otto M, Antuono P, Jacoby M, Richter R, Stevens J, Melamed I, Goldstein J, Haag S, Wietek S, Farlow M, Jessen F (2013) Intravenous immunoglobulin for treatment of mild-to-moderate Alzheimer's disease: a phase 2, randomised, double-blind, placebo-controlled, dose-finding trial. The Lancet Neurology 12, 233-243.

37. Arai H, Ichimiya Y, Shibata N, Nakajima T, Sudoh S, Tokuda T, Sujaku T, Yokokawa S, Hoshii N, Noguchi H, et al. (2014) Safety and tolerability of immune globulin intravenous (human), $10 \%$ solution in Japanese subjects with mild to moderate Alzheimer's disease. Psychogeriatrics: the official journal of the Japanese Psychogeriatric Society 14, 165-174.

38. Raphaël JC, Chevret S, Hughes RA, Annane D (2012) Plasma exchange for Guillain-Barré syndrome. Cochrane Database of Systematic Reviews.

39. Trebst C, Reising A, Kielstein JT, Hafer C, Stangel MJBp (2009) Plasma exchange therapy in steroid-unresponsive relapses in patients with multiple sclerosis. 28, 108-115.

40. Xu D, Wu J, Wu J, Xu C, Zhang Y, Mei C, Gao XJE, medicine t (2016) Novel therapy for anti-glomerular basement membrane disease with IgA nephropathy: a case report. Exp Ther Med 11, 1889-1892.

41. Kheifets V, Braithwaite SP (2019) Plasma-Based Strategies for Therapeutic Modulation of Brain Aging. Neurotherapeutics 16, 675684.

42. Tapiola T, Alafuzoff I, Herukka S-K, Parkkinen L, Hartikainen P, Soininen H, Pirttilä TJAon (2009) Cerebrospinal fluid $\beta$-amyloid 42 and tau proteins as biomarkers of Alzheimer-type pathologic changes in the brain. Arch Neurol 66, 382-389.

Page 10/16 
43. Hyman BT, Phelps CH, Beach TG, Bigio EH, Cairns NJ, Carrillo MC, Dickson DW, Duyckaerts C, Frosch MP, Masliah EJAs, dementia (2012) National Institute on Aging-Alzheimer's Association guidelines for the neuropathologic assessment of Alzheimer's disease. Alzheimers Dement 8, 1-13.

44. Rebo J, Mehdipour M, Gathwala R, Causey K, Liu Y, Conboy MJ, Conboy IMJNc (2016) A single heterochronic blood exchange reveals rapid inhibition of multiple tissues by old blood. Nat Commun 7, 1-11.

45. Smith LK, He Y, Park J-S, Bieri G, Snethlage CE, Lin K, Gontier G, Wabl R, Plambeck KE, Udeochu JJNm (2015) 32 -microglobulin is a systemic pro-aging factor that impairs cognitive function and neurogenesis. Nat Med 21, 932-937.

46. Villeda SA, Luo J, Mosher KI, Zou B, Britschgi M, Bieri G, Stan TM, Fainberg N, Ding Z, Eggel AJN (2011) The ageing systemic milieu negatively regulates neurogenesis and cognitive function. Nature 477, 90-94.

47. Kang JS, Yang YRJA (2020) Circulating plasma factors involved in rejuvenation. Aging (Albany NY) $12,23394$.

48. Bettcher BM, Fitch R, Wynn MJ, Lalli MA, Elofson J, Jastrzab L, Mitic L, Miller ZA, Rabinovici GD, Miller BLJAs, Dementia: Diagnosis A, Monitoring D (2016) MCP-1 and eotaxin-1 selectively and negatively associate with memory in $\mathrm{MCl}$ and Alzheimer's disease dementia phenotypes. Alzheimers Dement (Amst) 3, 91-97.

49. Parajuli B, Horiuchi H, Mizuno T, Takeuchi H, Suzumura AJG (2015) CCL11 enhances excitotoxic neuronal death by producing reactive oxygen species in microglia. Glia 63, 2274-2284.

50. Castellano JM, Mosher KI, Abbey RJ, McBride AA, James ML, Berdnik D, Shen JC, Zou B, Xie XS, Tingle MJN (2017) Human umbilical cord plasma proteins revitalize hippocampal function in aged mice. Nature 544, 488-492.

51. Gan KJ, Südhof TCJPotNAoS (2019) Specific factors in blood from young but not old mice directly promote synapse formation and NMDA-receptor recruitment. Proc Natl Acad Sci U S A 116, 12524-12533.

52. Castellano JM, Mosher KI, Abbey RJ, McBride AA, James ML, Berdnik D, Shen JC, Zou B, Xie XS, Tingle M, Hinkson IV, Angst MS, Wyss-Coray T (2017) Human umbilical cord plasma proteins revitalize hippocampal function in aged mice. Nature 544, 488-492.

53. Hsu CC, Serio A, Amdursky N, Besnard C, Stevens MM (2018) Fabrication of Hemin-Doped Serum Albumin-Based Fibrous Scaffolds for Neural Tissue Engineering Applications. ACS Appl Mater Interfaces 10, 5305-5317.

54. Mehdipour M, Skinner C, Wong N, Lieb M, Liu C, Etienne J, Kato C, Kiprov D, Conboy MJ, Conboy IMJA (2020) Rejuvenation of three germ layers tissues by exchanging old blood plasma with saline-albumin. Aging (Albany NY) 12, 8790.

55. Haass C, Kaether C, Thinakaran G, Sisodia S (2012) Trafficking and proteolytic processing of APP. Cold Spring Harbor perspectives in medicine 2, a006270.

56. Magga J, Puli L, Pihlaja R, Kanninen K, Neulamaa S, Malm T, Härtig W, Grosche J, Goldsteins G, Tanila H (2010) Human intravenous immunoglobulin provides protection against $A \beta$ toxicity by multiple mechanisms in a mouse model of Alzheimer's disease. Journal of neuroinflammation 7, 1-15.

57. Monfort JC, Lezy AM, Papin A, Tezenas du Montcel S (2020) Psychogeriatric Inventory of Disconcerting Symptoms and Syndromes (PGI-DSS): validity and reliability of a new brief scale compared to the Neuropsychiatric Inventory for Nursing Homes (NPI-NH). Int Psychogeriatr 32, 1085-1095.

58. Panza F, Lozupone M, Bellomo A, Imbimbo BPJArr (2019) Do anti-amyloid- $\beta$ drugs affect neuropsychiatric status in Alzheimer's disease patients? AGEING RES REV 55, 100948.

59. Holmgren S, Hjorth E, Schultzberg M, Lärksäter M, Frenkel D, Tysen-Bäckström AC, Aarsland D, Freund-Levi YJBrb (2014) Neuropsychiatric symptoms in dementia-A role for neuroinflammation? Brain Res Bull 108, 88-93.

60. Kessel A, Ammuri H, Peri R, Pavlotzky ER, Blank M, Shoenfeld Y, Toubi E (2007) Intravenous immunoglobulin therapy affects T regulatory cells by increasing their suppressive function. J Immunol 179, 5571-5575.

61. Kozicky LK, Zhao ZY, Menzies SC, Fidanza M, Reid GS, Wilhelmsen K, Hellman J, Hotte N, Madsen KL, Sly LM (2015) Intravenous immunoglobulin skews macrophages to an anti-inflammatory, IL-10-producing activation state. J Leukoc Bio/ 98, 983-994.

62. Welles CC, Tambra S, Lafayette RA (2010) Hemoglobinuria and acute kidney injury requiring hemodialysis following intravenous immunoglobulin infusion. Am J Kidney Dis 55, 148-151.

63. Katz U, Achiron A, Sherer Y, Shoenfeld Y (2007) Safety of intravenous immunoglobulin (IVIG) therapy. Autoimmun Rev 6, $257-259$.

64. Dodel R, Balakrishnan K, Keyvani K, Deuster O, Neff F, Andrei-Selmer LC, Röskam S, Stüer C, Al-Abed Y, Noelker C, Balzer-Geldsetzer M, Oertel W, Du Y, Bacher M (2011) Naturally occurring autoantibodies against beta-amyloid: investigating their role in transgenic animal and in vitro models of Alzheimer's disease. J Neurosci 31, 5847-5854.

65. Magga J, Puli L, Pihlaja R, Kanninen K, Neulamaa S, Malm T, Härtig W, Grosche J, Goldsteins G, Tanila H, Koistinaho J, Koistinaho M (2010) Human intravenous immunoglobulin provides protection against A $\beta$ toxicity by multiple mechanisms in a mouse model of

Page 11/16 
Alzheimer's disease. J Neuroinflammation 7, 90.

66. Du Y, Wei X, Dodel R, Sommer N, Hampel H, Gao F, Ma Z, Zhao L, Oertel WH, Farlow M (2003) Human anti-beta-amyloid antibodies block beta-amyloid fibril formation and prevent beta-amyloid-induced neurotoxicity. Brain 126, 1935-1939.

67. Käsermann F, Boerema DJ, Rüegsegger M, Hofmann A, Wymann S, Zuercher AW, Miescher S (2012) Analysis and functional consequences of increased Fab-sialylation of intravenous immunoglobulin (IVIG) after lectin fractionation. PLoS One 7, e37243.

68. Taniguchi T, Sumida M, Hiraoka S, Tomoo K, Kakehi T, Minoura K, Sugiyama S, Inaka K, Ishida T, Saito N, Tanaka C (2005) Effects of different anti-tau antibodies on tau fibrillogenesis: RTA-1 and RTA-2 counteract tau aggregation. FEBS Lett 579, $1399-1404$.

69. Lee SJ, Nam E, Lee HJ, Savelieff MG, Lim MH (2017) Towards an understanding of amyloid- $\beta$ oligomers: characterization, toxicity mechanisms, and inhibitors. Chem Soc Rev 46, 310-323.

70. Schneider L (2020) A resurrection of aducanumab for Alzheimer's disease. Lancet Neurol 19, 111-112.

71. Moussa-Pacha NM, Abdin SM, Omar HA, Alniss H, Al-Tel TH (2020) BACE1 inhibitors: Current status and future directions in treating Alzheimer's disease. Med Res Rev 40, 339-384.

72. Lessard CB, Rodriguez E, Ladd TB, Minter LM, Osborne BA, Miele L, Golde TE, Ran Y (2020) Y-Secretase modulators exhibit selectivity for modulation of APP cleavage but inverse $Y$-secretase modulators do not. Alzheimers Res Ther 12, 61.

73. Yang G, Zhou R, Guo X, Yan C, Lei J, Shi Y (2021) Structural basis of Y-secretase inhibition and modulation by small molecule drugs. Cell 184, 521-533.e514.

74. Hannestad J, Koborsi K, Klutzaritz V, Chao W, Ray R, Páez A, Jackson S, Lohr S, Cummings JL, Kay G, Nikolich K, Braithwaite S (2020) Safety and tolerability of GRF6019 in mild-to-moderate Alzheimer's disease dementia. Alzheimers Dement (N Y) 6, e12115.

75. Hannestad J, Duclos T, Chao W, Koborsi K, Klutzaritz V, Beck B, Patel AK, Scott J, Thein SG, Cummings JL, Kay G, Braithwaite S, Nikolich K (2021) Safety and Tolerability of GRF6019 Infusions in Severe Alzheimer's Disease: A Phase II Double-Blind PlaceboControlled Trial. J Alzheimers Dis 81, 1649-1662.

76. Fei Z, cheng Z, Du X, Cao H, Li C (2021) Progress on the effect of ApoE4 in Alzheimer disease. Journal of Neuroscience and Mental Health 21, 365-371.

77. Relkin N (2013) Results of GAP (160701): a Phase III study of intravenous gammaglobulin for the treatment of mild to moderate Alzheimer's disease. AAIC, Boston.

\section{Figures}




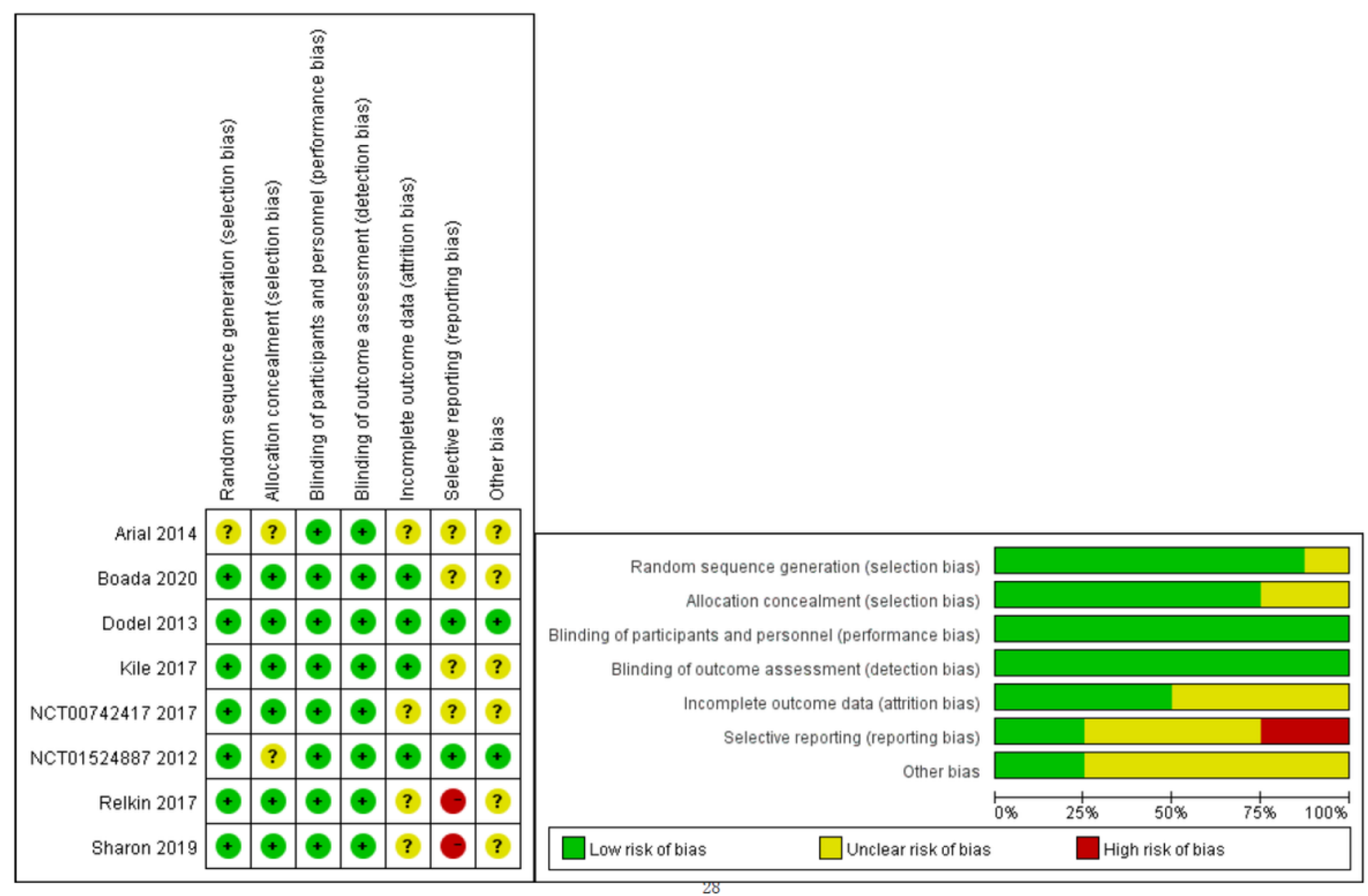

Figure 1

Assessment for risk of bias in included studies 


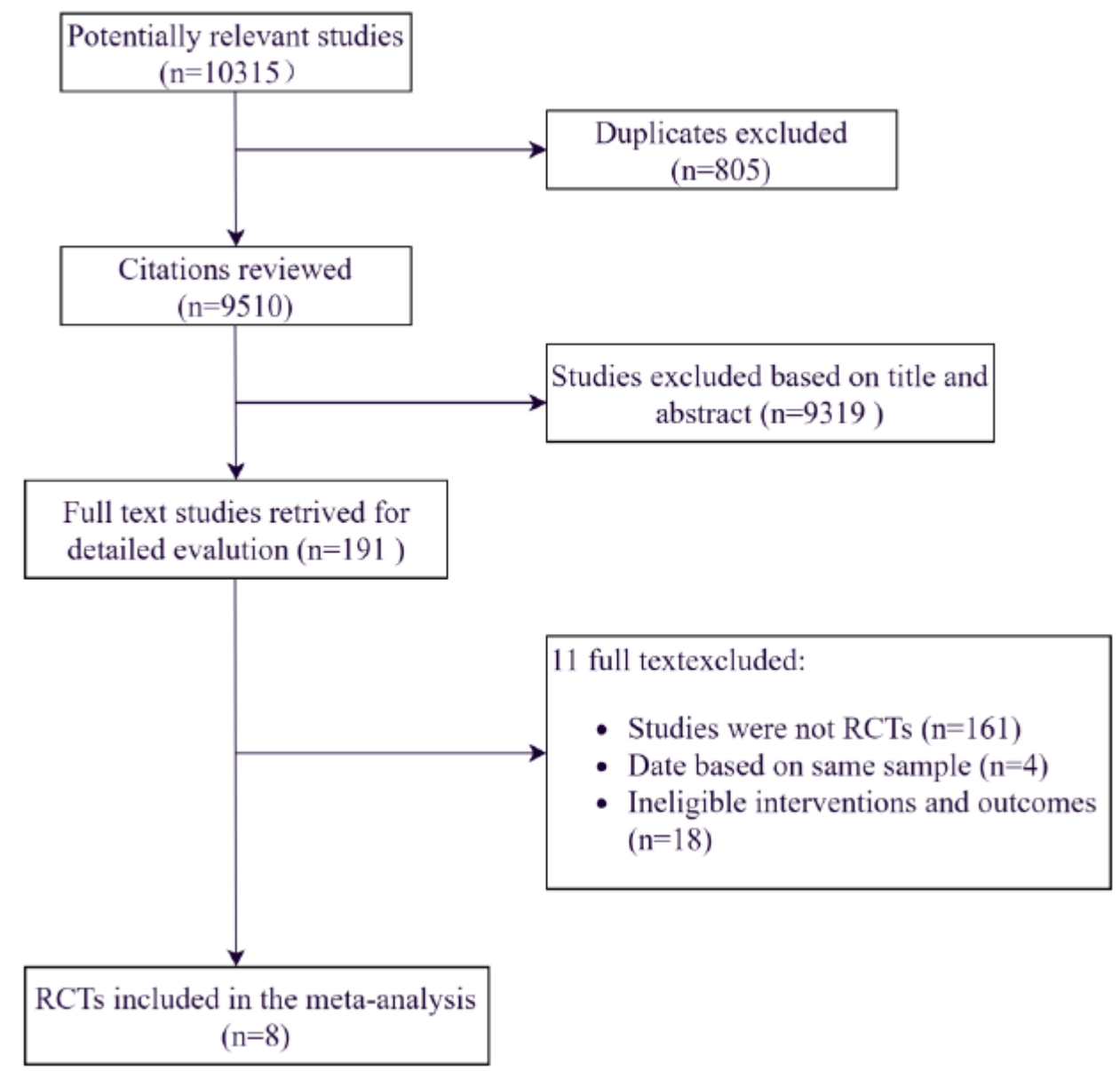

\section{Figure 2}

Study flow diagram 

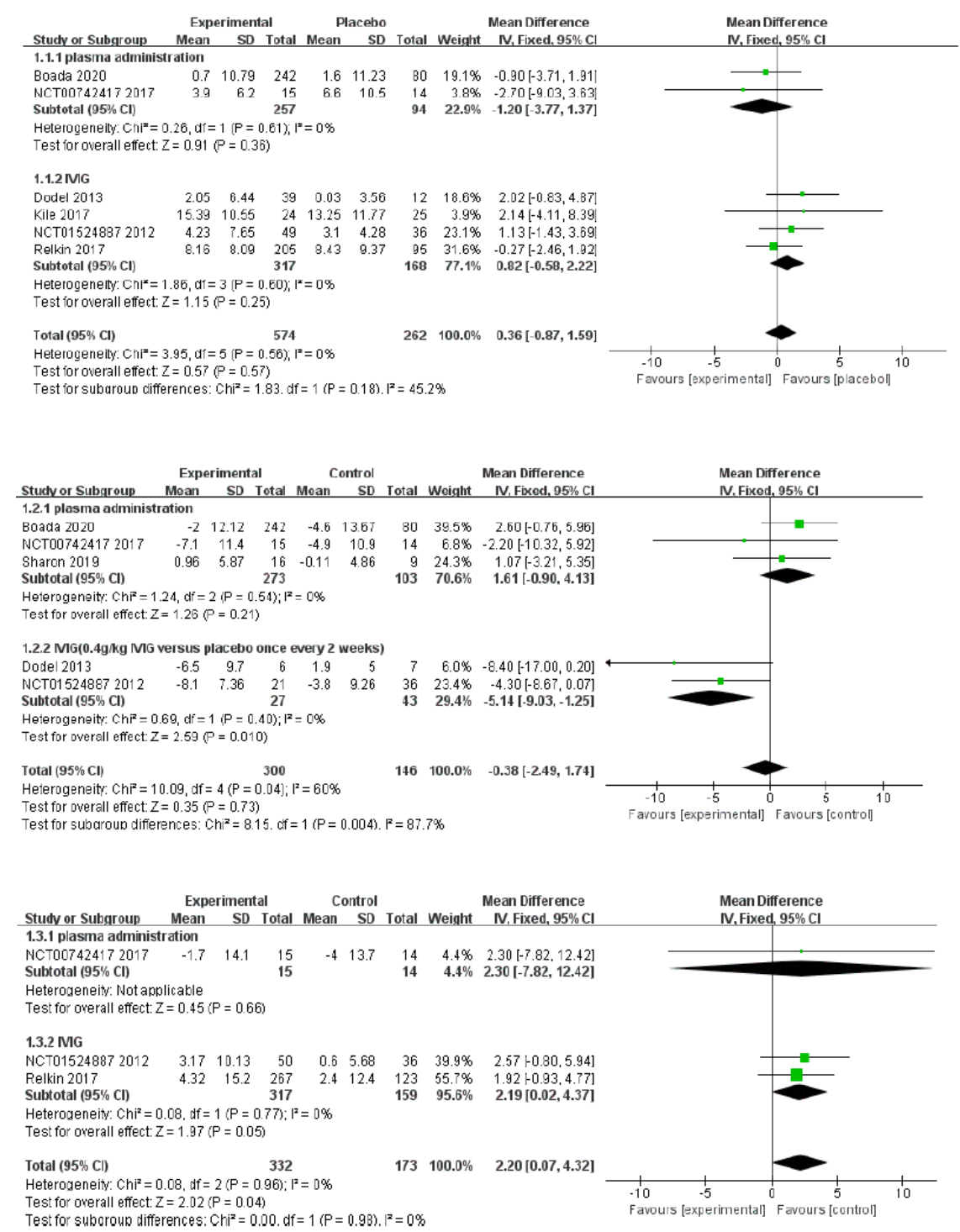

\section{Figure 3}

a. Forest plots of ADAS-Cog scores (6 comparisons, $n=836$ ) b. Forest plots of ADCS-ADL scores ( 5 comparisons, $n=446)$ c. Forest plots of NPI scores (3 comparisons, $n=505$ ) 


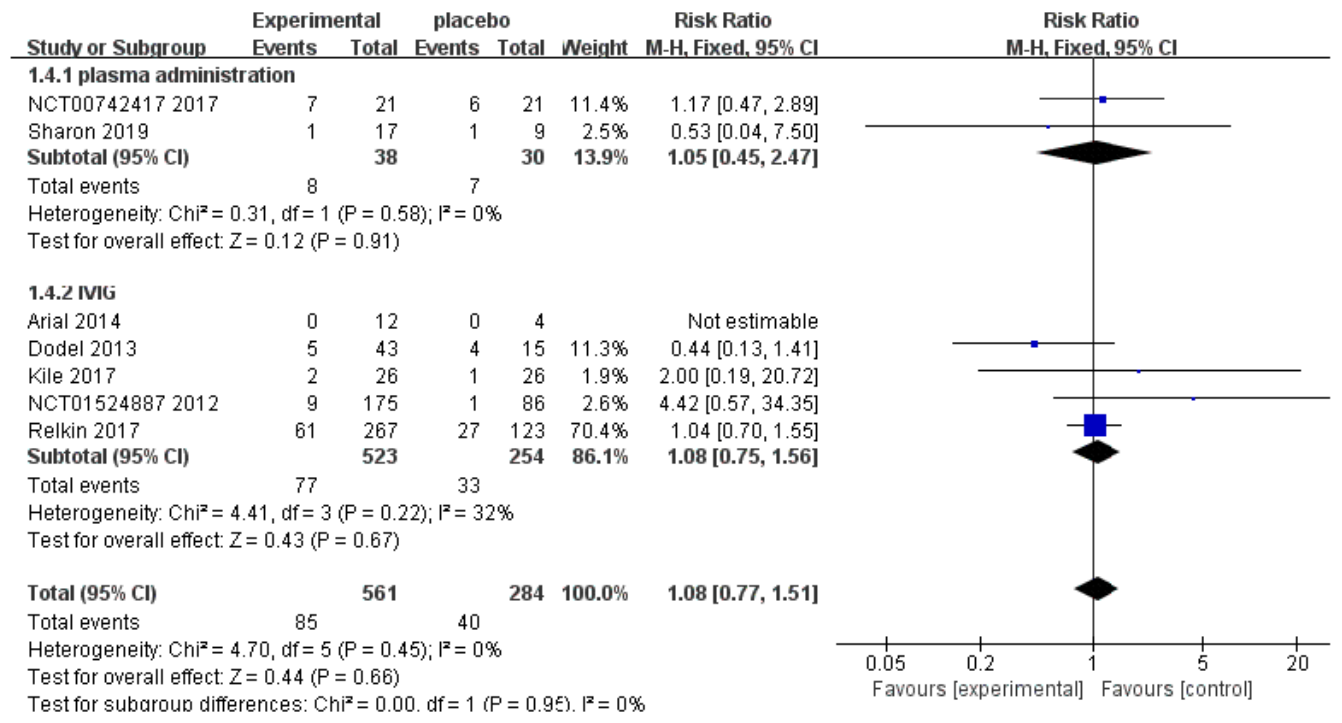

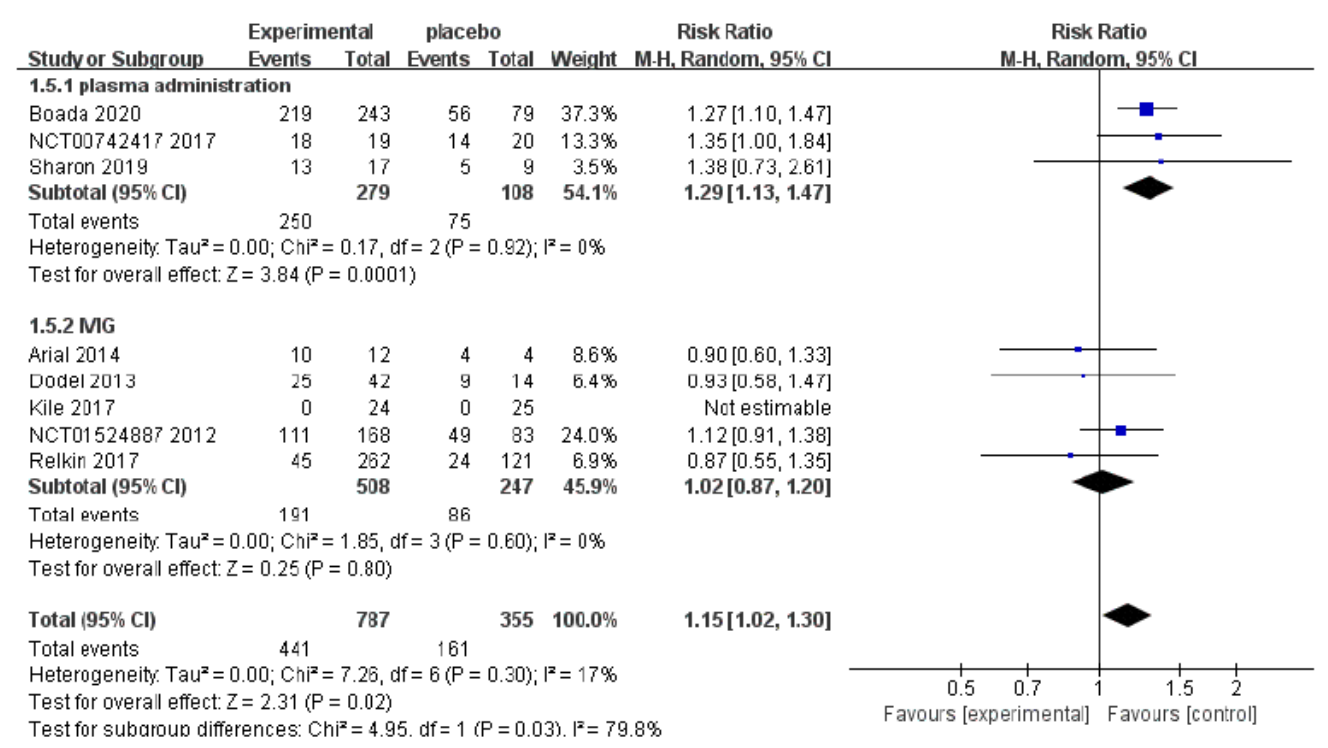

\section{Figure 4}

a. Forest plots of all-cause discontinuation rates ( 7 comparisons, $n=845$ )

b. Forest plots of adverse events ( 8 comparisons, $n=1142$ )

\section{Supplementary Files}

This is a list of supplementary files associated with this preprint. Click to download.

- Supplementary.doc 